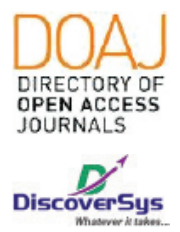

Published by DiscoverSys

\title{
Karakteristik infeksi virus dengue pada pasien anak di poliklinik anak Rumah Sakit Umum Pusat (rsup) Sanglah, Denpasar tahun 2016
}

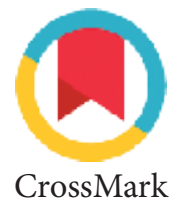

\author{
I Made Bagus Wilaksmana Putra, ${ }^{1 *}$ I Nyoman Budi Hartawan, ${ }^{2}$ \\ I Wayan Gustawan ${ }^{2}$
}

CrossMark

\section{ABSTRACT}

Background: Dengue infection is a mosquito induced viral infection with the highest virility level in the world. This disease is an international emergency problem and creates economic and social burdens around the world. Therefore, this study aims to determine the characteristics of dengue virus infection in pediatric patients in 2016 based on several parameters.

Methods: A cross-sectional study was conducted among 96 pediatric patients with dengue virus infection who were treated at Sanglah General Hospital, Bali in 2016 period. A secondary data obtained from the collection of medical records of patients were used in this study. Data were analyzed using Microsoft Excel 2010 for Windows software. Results: Most of patients were female (54.17\%), aged 5-18 years (67.71\%), and with normal BMI status (42.71\%). Most subject comes with bleeding signs and have positive tourniquets tests (64.58\%), followed by abdominal clinical symptoms with nausea (50.00\%), and neurological status with headache (41.67\%). The length of stay of patients were mostly 3-5 days (73.96\%) and the results of the axial temperature examination at the time of hospital admission were dominant $\angle 37^{\circ} \mathrm{C}(65.63 \%)$. Based on laboratory examination, most subject has hemoglobin examination of 11-13 g/dl (57.29\%), platelet examination results 50,000-100,000 (65.63\%), hematocrit examination results $<41 \%(44.79 \%)$, and leukocyte examination results $<5,000 / \mu \mathrm{l}$ (59.38\%). Most subjects are patient with Grade I DHF (56.25\%\%).

Conclusion: The most predominant characteristics of pediatric patients with dengue virus infection was female, bleeding signs, nausea, headache, 3-5 days length of stay, atypical hematological parameters such as on hematocrit, platelet, and leucocyte examination.
'Program Studi Pendidikan Dokter, Fakultas Kedokteran, Universitas Udayana, Denpasar, Indonesia ${ }^{2}$ SMF IImu Kesehatan Anak, Fakultas Kedokteran, Universitas Udayana, RSUP Sanglah Denpasar, Indonesia

\section{*Korespondensi:}

I Made Bagus Wilaksmana Putra; Program Studi Pendidikan Dokter, Fakultas Kedokteran, Universitas Udayana, Denpasar, Indonesia; madewilaksmana@gmail.com

Diterima: 11-06-2019

Disetujui: 03-01-2020

Diterbitkan: 01-04-2020
Keywords: dengue viral infection, characteristic, pediatric.

Cite This Article: Putra, I.M.B.W., Hartawan, I.N.B., Gustawan, I.W. 2020. Karakteristik infeksi virus dengue pada pasien anak di poliklinik anak Rumah Sakit Umum Pusat (rsup) Sanglah, Denpasar tahun 2016. Intisari Sains Medis 11(1): 28-34. D0I: 10.15562/ism.v11i1.521

\section{ABSTRAK}

Latar Belakang: Penyakit infeksi dengue merupakan penyakit infeksi virus vektor nyamuk dengan tingkat penyebaran tertinggi di dunia. Penyakit ini seringkali menjadi masalah darurat antarnegara serta menimbulkan beban ekonomi dan sosial di dunia. Oleh karena itu, penelitian ini bertujuan untuk mengetahui karakteristik infeksi virus dengue pada pasien anak tahun 2016 berdasarkan beberapa parameter.

Metode: Sebuah studi potong lintang dilakukan pada 96 pasien anak-anak dengan infeksi virus dengue yang dirawat di Rumah Sakit Umum Pusat Sanglah, Bali pada periode tahun 2016. Data sekunder yang diperoleh dari rekam medis pasien digunakan dalam penelitian ini. Data dianalisis menggunakan piranti lunak Microsoft Excel 2010 untuk Windows.

Hasil: Sebagian besar pasien adalah perempuan $(54,17 \%)$, berusia 5-18 tahun $(67,71 \%)$, dan dengan status BMI normal $(42,71 \%)$.
Sebagian besar subjek datang dengan tanda-tanda perdarahan dan memiliki tes tourniquets positif $(64,58 \%)$, diikuti oleh gejala klinis perut mual $(50,00 \%)$, dan status neurologis dengan sakit kepala (41,67\%). Lama tinggal pasien sebagian besar 3-5 hari $(73,96 \%)$ dan hasil pemeriksaan suhu aksial saat masuk rumah sakit didominasi $<37^{\circ} \mathrm{C}(65,63 \%)$. Berdasarkan pemeriksaan laboratorium, sebagian besar subjek memiliki pemeriksaan hemoglobin 11-13 g/dl (57,29\%), hasil pemeriksaan trombosit 50.000-100.000 (65,63\%), hasil pemeriksaan hematokrit $<41 \%(44,79 \%)$, dan hasil pemeriksaan leukosit $<5.000 / \mu \mathrm{l}(59,38 \%)$. Sebagian besar subyek adalah pasien dengan DBD kelas I (56,25\%\%).

Kesimpulan: Karakteristik yang paling dominan dari pasien anak dengan infeksi virus dengue adalah wanita, tanda-tanda perdarahan, mual, sakit kepala, 3-5 hari tinggal, parameter hematologis khusus seperti pada hematokrit, trombosit, dan pemeriksaan leukosit.
Kata Kunci: Infeksi Virus Dengue, karakteristik, pediatri.

Cite Pasal Ini: Putra, I.M.B.W., Hartawan, I.N.B., Gustawan, I.W. 2020. Karakteristik infeksi virus dengue pada pasien anak di poliklinik anak Rumah Sakit Umum Pusat (rsup) Sanglah, Denpasar tahun 2016. Intisari Sains Medis 11(1): 28-34. D0I: 10.15562/ism.v11i1.521 


\section{PENDAHULUAN}

Penyakit infeksi dengue merupakan penyakit infeksi virus vektor nyamuk dengan tingkat penyebaran tertinggi di dunia. Penyakit ini seringkali menjadi masalah darurat antarnegara dan menimbulkan permasalahan ekonomi dan soial di dunia. ${ }^{1}$ Jumlah kasus infeksi virus dengue (IVD) di dunia saat ini diperkirakan mencapai 96 juta jiwa, dengan jumlah kasus per tahun rata-rata mencapai 1 juta jiwa dan kerugian akibat pengobatannya mencapai 175 milyar dolar amerika. Kasus IVD juga telah menjadi penyakit endemi di lebih dari 112 negara di dunia dan bertanggung jawab atas lebih dari 9000 kematian per tahun. ${ }^{2}$

Wilayah Asia sendiri menyumbang sekitar 70\% dari total kasus IVD yang terjadi di dunia dengan jumlah kasus yang terjadi sekitar 66 juta kasus dengan dampak wilayah terparah terjadinya kasus IVD terdapat di Asia Tenggara. ${ }^{3}$ Di Asia Tenggara IVD telah mewabah hampir seluruh negara bagiannya, dan tercatat telah menyebabkan Vietnam, Myanmar, Malaysia, Thailand, dan Indonesia mengalami kerugian jutaan dolar amerika untuk perawatan IVD setiap tahunnya. ${ }^{4}$ Indonesia sendiri termasuk negara dengan jumlah kasus IVD yang tertinggi di Asia bersama India, Sri Langka dan Bangladesh. ${ }^{5}$ Kasus IVD di Indonesia sudah tersebar di 34 provinsi yang ada di Indonesia, namun provinsi-provinsi yang ada di pulau sumatera, kalimantan, dan sulawesi juga memiliki endemi infeksi vektor nyamuk yang lain seperti malaria dan cikhungunya selain infeksi dengue. ${ }^{6}$

Provinsi Bali merupakan salah satu provinsi yang merupakan endemi terbesar virus dengue dan salah satu penyumbang kasus IVD terbanyak di Indonesia. Pada tahun 2010 Provinsi Bali tercatat menyumbang sekitar $8 \%$ dari kasus IVD di Indonesia dan merupakan provinsi urutan tertinggi ke-4 untuk kasus ini. Padahal Provinsi Bali hanya memiliki luas $0.31 \%$ dari total luas wilayah Indonesia, dan dihuni hanya sekitar 1.6\% total penduduk Indonesia. ${ }^{7}$ Bali juga merupakan salah satu tempat tujuan pariwisata terkenal baik di Indonesia maupun mancanegara dan memiliki peran yang penting dalam penyebaran kasus IVD. Sekitar 20\% kasus IVD yang ditemukan di Jepang ternyata diteliti berasal dari Bali, berdasarkan pemeriksaan serotip virus ditemukan serotip virus yang menginfeksi merupakan virus yang mayoritas berada di Bali. ${ }^{8}$

Penyakit infeksi dengue secara umum dapat terbagi atas 3 jenis penyakit dengan gejala klinis yang berbeda, yaitu demam dengue, demam berdarah dengue, dan sindrom syok dengue. Demam dengue ditandai dengan gejala klinis flu-like symptom seperti demam, batuk, pilek, pusing, yang cukup ringan. Sementara demam berdarah dengue ditandai dengan gejala klinis yang ditemukan lebih berat dan serius dan dapat disertai dengan adanya tanda pendarahan. Sindrom syok dengue ditandai dengan gejala yang sangat berat dan mengancam nyawa pasien apabila tidak mendapatkan penanganan segera. ${ }^{9}$ Infeksi dengue merupakan penyakit tropis yang terjadi akibat dari adanya infeksi virus dengue. Penyakit ini merupakan penyakit epidemi yang biasanya terdapat pada negara-negara yang terletak pada $23,5^{\circ} \mathrm{LU}-23,5^{\circ} \mathrm{LS}$ bumi atau beriklim tropis. ${ }^{10}$ Penularan virus dengue dapat terjadi melalui vektor nyamuk yaitu nyamuk jenis Aedes. Nyamuk jenis Aedes adalah salah satu faktor penting penularan penyakit tropis di dunia karena selain menjadi vektor virus dengue, nyamuk jenis ini juga menjadi vektor untuk berbagai penyakit tropis lain seperti cikhungunya, demam kuning, dan demam zika. $^{3}$

Berdasarkan pada pemaparan di atas, maka penelitian ini bertujuan untuk mengetahui lebih lanjut mengenai karakteristik infeksi virus dengue pada pasien anak di poliklinik anak Rumah Sakit Umum Pusat (rsup) Sanglah, Denpasar tahun 2016.

\section{METODE PENELITIAN}

Penelitian ini menggunakkan metode deskriptif observasional dengan rancangan potong lintang dimana penelitian dilaksanakan di Divisi Infeksi Tropik, Ilmu Kesehatan Anak RSUP Sanglah menggunakkan data retrospektif dari bulan Januari 2016 - Maret 2016. Subyek penelitian yang digunakkan berasal dari populasi yang telah memenuhi kriteria inklusi yaitu pasien usia 0-18 tahun yang dirawat di RSUP Sanglah yang telah memenuhi kriteria diagnosis WHO untuk demam dengue, demam berdarah dengue, atau sindrom syok dengue, dari bulan Januari 2016 - Maret 2016 serta memiliki rekam medis yang lengkap

Metode penentuan sampel yang digunakkan adalah random sampling. Jumlah sampel digitung menggunakkan rumus besar sampel dalam proporsi infeksi virus dengue di kota denpasar dimana $\mathrm{P}=$ 0,31 dan $\mathrm{Q}=1-\mathrm{P}=0,69$. Besar ketetapan relatif yang ditetapkann yaitu $10 \%(\mathrm{~d}=0,1)$. Besarnya $\mathrm{Za}=1,96$. Sehingga besar sampel yang dibutuhkan minimal 82 orang pasien sebagai subjek penelitian. Dari hasil pengambilan sampel retrospektif bulan Januari 2016 - Maret 2016 didapatkan jumlah sampel yang memenuhi kriteria inklusi sebanyak 96 pasien.

Data berupa data sekunder yang dikumpulkan melalui pengambilan data rekam medik pasien infeksi virus dengue yang dirawat di RSUP Sanglah dari bulan Januari 2016 sampai Maret 2016. Data yang digunakkan dari rekam medik berupa 
karakteristik pasien meliputi usia, jenis kelamin, status gizi tanda pendarahan, status neurologis, tanda abdominal, lama perawatan, temperatur aksilar jumlah hemoglobin, leukosit, hematokrit, platelet, serta derajat keparahan infeksi. Data kemudian dianalisis dengan bantuan piranti lunak Microsoft Excel 2010 untuk Windows.

\section{HASIL PENELITIAN}

Hasil penelitian pada Tabel 1 menunjukkan bahwa dari 96 pasien subjek penelitian, berdasarkan demografinya ditemukan jenis kelamin yang lebih dominan adalah perempuan sebanyak 44 pasien $(54,17 \%)$. Rentang usia terbanyak yang ditemukan adalah pada rentang 5-18 tahun yaitu sebanyak 65 pasien $(67,71 \%)$. Berdasarkan indeks masa tubuhnya, pasien terbanyak ditemukan pada indeks masa tubuh normal $(42,71 \%)$, diikuti kurang $(23,96 \%)$, sangat kurang (12,5\%), serta obesitas dan overweight dengan jumlah yang sama (10,42\%) (Tabel 1).

Berdasarkan gejala klinisnya pada pasien yang dirawat di RSUP Sanglah paling banyak memiliki gejala tanda pendarahan, dimana salah satu tanda terbanyak adalah tes torniquette yang positif $(64,58 \%)$ (Tabel 1). Pasien yang datang dengan gejala abdominal paling banyak dengan gejala mual/nausea (50\%). Pasien dengan gejala neurologis, paling banyak datang dengan gejala nyeri kepala (41,67\%). Pasien yang dirawat di RSUP sanglah dominan dirawat selama 3-5 hari $(73,69 \%)$. Sementara temperatur aksila pada saat masuk rumah sakit terbanyak adalah $<37^{\circ} \mathrm{C}(65,63 \%)$ (Tabel 1).

Pada Tabel 1 juga dapat dilihat distribusi pasien berdasarkan pemeriksaan laboratorium. Pasien yang dirawat di RSUP Sanglah dengan pemeriksaan kadar hemoglobin 11-13 / $\mu$ l paling banyak dijumpai (57,29\%), sementara pemeriksaan kadar trombosit 50.000-100.000/ $/ \mu$ pada pasien paling banyak dijumpai. Pasien dengan kadar hematokrit $<41 \%$ dominan ditemui (44,79\%), dan kadar leukosit $<5$ juga dominan ditemui (59,38\%) (Tabel 1).

Apabila dilihat berdasarikan derajat infeksi pasien maka didapatkan pasien dengan infeksi derajat 1 paling banyak ditemui $(56,25 \%)$, diikuti derajat $3(16,67 \%)$, derajat $4(14,58 \%)$, dan derajat $2(12,5 \%)$. Selanjutnya perempuan lebih banyak dijumpai pada kasus infeksi ringan (derajat 1 dan 2) dibandingkan laki-laki, sementara pada kasus infeksi berat (derajat 3 dan 4) perbandingan lakilaki dan perempuan relatif sama (Tabel 1).

\section{Tabel 1 Distribusi frekuensi pasien infeksi virus dengue berdasarkan karakteristik demografi}

\begin{tabular}{|c|c|c|c|}
\hline Karakteristik & Frekuensi ( $\mathrm{N}=96)$ & Persentase (\%) & Persentase Gejala (\%) \\
\hline \multicolumn{4}{|l|}{ Jenis Kelamin (\%) } \\
\hline Laki-Laki & 44 & 45.83 & \\
\hline Perempuan & 52 & 54.17 & \\
\hline \multicolumn{4}{|l|}{ Usia (Tahun) } \\
\hline 0-5 Tahun & 31 & 32.29 & \\
\hline 5-18 Tahun & 65 & 67.71 & \\
\hline \multicolumn{4}{|l|}{ Indeks Massa Tubuh (kg/m2) } \\
\hline Obesitas & 10 & 10.42 & \\
\hline Overweight & 10 & 10.42 & \\
\hline Normal & 41 & 42.71 & \\
\hline Kurang & 23 & 23.96 & \\
\hline Sangat Kurang & 12 & 12.50 & \\
\hline \multicolumn{4}{|l|}{ Lama Perawatan } \\
\hline 1-2 Hari & 18 & 18.75 & \\
\hline 3-5 Hari & 71 & 73.96 & \\
\hline 5-7 Hari & 7 & 7.29 & \\
\hline Tanda Pendarahan $(\mathrm{N}=66)$ & & & 68.75 \\
\hline Torniquette & 62 & 64.58 & \\
\hline Bercak merah & 7 & 7.29 & \\
\hline Petechie & 8 & 8.33 & \\
\hline Epitaksis & 10 & 10.42 & \\
\hline
\end{tabular}


Tabel 1 Continue

\begin{tabular}{|c|c|c|c|}
\hline Karakteristik & Frekuensi ( $\mathrm{N}=96)$ & Persentase (\%) & Persentase Gejala (\%) \\
\hline Gejala Abdominal $(\mathrm{N}=62)$ & & & 64.58 \\
\hline Muntah & 39 & 40.63 & \\
\hline Nausea & 48 & 50.00 & \\
\hline Nyeri perut & 32 & 33.33 & \\
\hline Diare & 2 & 2.08 & \\
\hline \multicolumn{4}{|l|}{ Gejala Neurologis $(\mathrm{N}=41)$} \\
\hline Sakit kepala & 40 & 41.67 & \\
\hline Penurunan kesadaran & 1 & 1.04 & \\
\hline Temperatur Aksila MRS & & & 42.71 \\
\hline$<37$ & 63 & 65.63 & \\
\hline $37-38$ & 20 & 20.83 & \\
\hline$>38$ & 13 & 13.54 & \\
\hline \multicolumn{4}{|l|}{ Kadar Hemoglobin } \\
\hline$<11$ & 10 & 10.42 & \\
\hline $11.0-13.0$ & 55 & 57.29 & \\
\hline$>13$ & 31 & 32.29 & \\
\hline \multicolumn{4}{|l|}{ Kadar Trombosit } \\
\hline$<50$ & 23 & 23.96 & \\
\hline $50-100$ & 63 & 65.63 & \\
\hline$>100$ & 10 & 10.42 & \\
\hline \multicolumn{4}{|l|}{ Kadar Hematokrit } \\
\hline$<41$ & 43 & 44.79 & \\
\hline $41-46$ & 33 & 34.38 & \\
\hline$>46$ & 20 & 20.83 & \\
\hline \multicolumn{4}{|l|}{ Kadar Leukosit } \\
\hline$<5$ & 57 & 59.38 & \\
\hline $5-10$ & 29 & 30.21 & \\
\hline$>10$ & 10 & 10.42 & \\
\hline \multicolumn{4}{|l|}{ Derajat DHF (L/P) } \\
\hline $1(20 / 34)$ & 54 & 56.25 & \\
\hline $2(9 / 3)$ & 12 & 12.50 & \\
\hline $3(10 / 6)$ & 16 & 16.67 & \\
\hline $4(5 / 9)$ & 14 & 14.58 & \\
\hline
\end{tabular}

\section{PEMBAHASAN}

Hasil analisis data berdasarkan jenis kelamin, pasien anak infeksi virus dengue di RSUP Sanglah terbanyak adalah pasien perempuan. Pada penelitian yang dilakukan Raihan dkk, di RSU Dr Zainoel Abidin di Banda Aceh dari 276 pasien anak infeksi virus dengue, juga didapatkan dominan berjenis kelamin perempuan (50.3\%). ${ }^{11}$ Hasil juga sejalan dengan penelitian Rika dkk, di RSUP Dr. Kariadi Semarang, dimana pada 82 pasien anak infeksi virus dengue, $58.8 \%$ pasien berjenis kelamin perempuan. ${ }^{12}$ Namun hasil ini sedikit berbeda dari penelitian yang dilakukan Indah Jayani dkk, dimana RSUD Gambiran Kota Kediri dimana dari 49 pasien anak infeksi virus dengue, $51.2 \%$ berjenis kelamin laki-laki dan hanya $48.8 \%$ yang berjenis kelamin perempuan. ${ }^{13}$ Variasi ini terjadi kemungkinan disebabkan karena adanya perbedaan demografi jenis kelamin penduduk yang terjadi di setiap daerah.

Rentang usia subyek penelitian didapatkan terbanyak adalah pada rentangan umur 5-18 tahun. Hasil ini sejalan dengan penelitian Krisnanto 
dkk, di RSU Dr Sardjito Yogyakarta dimana dari 852 pasien anak infeksi virus dengue, pasien dengan usia 6-10 tahun adalah sebanyak 39.9\% pasien, pasien dengan usia $>11$ tahun adalah sebanyak $27.4 \%$, dan pasien dengan usia 0-5 tahun adalah sebanyak $32.7 \%{ }^{14}$ Usia diatas 5 tahun merupakan titik awal dimana anak mulai bersekolah, dan mulai bermain diluar pengawasan orangtua sehingga pada usia inilah anak kemungkinan lebih rentan mendapatkan paparan vektor infeksi virus dengue.

Berdasarkan status gizinya jumlah subyek penelitian terbanyak yaitu pasien dengan status gizi normal. Hasil yang didapatkan tidak jauh berbeda dari penelitian Indah Jayani dkk, di RSUD Gambiran Kota Kediri dimana dari 49 pasien anak infeksi virus dengue, pasien dengan gizi normal dominan sebanyak $53.5 \%$, diikuti dengan pasien gizi berlebih $32.6 \%$, dan pasien dengan gizi kurang dan buruk sebanyak $14 \% .{ }^{13}$ Anak dengan status gizi normal memiliki frekuensi infeksi terbanyak kemungkinan disebabkan oleh persebaran populasi anak dengan status gizi normal tinggi dibandingkan dengan anak dengan status gizi berlebih maupun kurang dengan infeksi virus dengue.

Berdasarkan status gizinya jumlah subyek penelitian terbanyak yaitu pasien yang menjalani rawat-inap di RSUP Sanglah selama 3-5 hari. Hasil ini cukup sejalan dengan penelitian Dominicus dkk, di RSU Dr Soetomo di Surabaya, dimana dari 53 pasien anak infeksi virus dengue, didapatkan rerata hari perawatan untuk pasien DBD adalah 4.33 hari, sedangkan rerata hari perawatan untuk pasien DD adalah 4.41 hari. ${ }^{15}$ Berdasarkan WHO, infeksi virus dengue biasanya berlangsung selama 6-7 hari dengan 3 fase berbeda. fase demam biasanya terjadi selama 2-7 hari, fase kritis terjadi di hari ke- 4 atau 5 infeksi, fase penyembuhan terjadi pada hari ke-6 dan 7. ${ }^{3}$ Lama perawatan pasien dominan selama 3-5 hari kemungkinan disebabkan oleh siklus demam infeksi virus dengue, dimana fase demam dapat terjadi selama 2-7 hari.

Berdasarkan tanda klinis pendarahan jumlah subyek penelitian terbanyak yaitu pasien dengan hasil tes torniquette positif, diikuti pasien dengan epistaksis, petechie, dan terakhir bercak kemerahan. Hasil ini cukup sesuai dengan penelitian sebelumnya oleh Rika dkk, dimana dari 82 pasien yang diperiksa terdapat $74 \%$ pasien dengan tanda klinis pendarahan. Hasil tersebut meliputi 46\% pasien dengan tes torniquette positif, dan $12 \%$ pasien epitaksis. ${ }^{12}$ Namun hasil ini sedikit berbeda dari penelitian sebelumnya oleh Danny dkk, di RSUD Dr A. Dadi Tjokrodipo Lampung dimana dari 33 pasien yang diperiksa terdapat $42.4 \%$ pasien dengan tes torniquette positif, terdapat $9 \%$ pasien dengan epitaksis, dan terdapat $30.1 \%$ pasien dengan gejala klinis petechie. ${ }^{16}$
Jumlah subyek penelitian dengan gejala abdominal berdasarkan data adalah sebanyak $64.58 \%$, dengan rincian terbanyak adalah pasien dengan gejala nausea, diikuti dengan gejala muntah, nyeri perut, dan terakhir pasien dengan gejala diare. Hasil ini tidak jauh berbeda dengan penelitian oleh Dila et al, di RS Dr. Kariadi dimana dari 50 subjek pasien anak-anak ditemukan 32\% kasus muntah, serta ditemukan $68 \%$ pasien mengalami gejala nyeri perut. ${ }^{17}$ Namun hasil ini cukup berbeda dari penelitian yang dilakukan oleh Dominicus dkk, dimana dari 53 pasien demam berdarah dengue neonatus ditemukan $55 \%$ pasien mengalami diare, dan $44 \%$ pasien mengalami gejala muntah. ${ }^{15}$

Jumlah subyek penelitian dengan gejala klinis neurologis berdasarkan data adalah $42.71 \%$, dengan rincian pasien terbanyak datang dengan gejala nyeri kepala datang, kemudian gejala penurunan kesadaran. Hasil ini cukup sesuai dengan penelitian yang dilakukan oleh Reni dkk, dimana dari 102 pasien infeksi virus dengue anak ditemukan $34 \%$ pasien mengalami nyeri kepala. ${ }^{18}$

Pemeriksaan hemoglobin subyek penelitian didapatkan terbanyak adalah pasien dengan rentang hemoglobin 11-13 g/dl, diikuti pasien dengan jumlah hemoglobin diatas $13 \mathrm{~g} / \mathrm{dl}$, dan paling sedikit adalah pasien dengan jumlah hemoglobin dibawah $11 \mathrm{~g} / \mathrm{dl}$. Hal ini dapat dibandingkan dengan penelitian Danny dkk, dimana dari 33 subjek pasien infeksi virus dengue anak ditemukan pasien dengan jumlah hemoglobin terbanyak adalah $<12$ g/dl yaitu sebanyak $54.55 \%$, sementara pasien dengan rentang hemoglobin 12-16 g/dl didapatkan sebanyak $36.36 \%$, dan pasien dengan jumlah hemoglobin $>16$ ditemukan $9.09 \% .{ }^{16}$ Hasil ini cukup sejalan dengan penelitian Dominicus dkk, dimana dari 53 pasien ditemukan rerata jumlah hemoglobin pada pasien DBD sebesar $11.6 \mathrm{~g} / \mathrm{dl}$, serta $11.26 \mathrm{~g} /$ dl pada pasien DD. ${ }^{15}$ Penurunan tekanan onkotik pada pembuluh kapiler, sebagai patofisiologi infeksi virus dengue dapat mempermudah terjadinya pendarahan pada pasien IVD. Penurunan kadar hemoglobin dapat terjadi akibat pendarahan yang hebat yang tidak diikuti kemampuan tubuh untuk menggantinya. ${ }^{19-20}$

Berdasarkan hasil pemeriksaan platelet/keping darah pada subyek penelitian, didapatkan pasien mengalami trombositopenia atau jumlah trombosit $<150.000 / \mu \mathrm{l}$ sebanyak $100 \%$, dengan rincian jumlah pasien terbanyak merupakan pasien dengan rentang trombosit 50.000-100.000/ $\mu \mathrm{l}$ (trombositopenia sedang), diikuti pasien dengan jumlah trombosit $<50.000 / \mu \mathrm{l}$ (trombositopenia berat), dan pasien dengan rentang trombosit 100.000-150.000/ $/ \mu \mathrm{l}$ (trombositopenia ringan). Hasil ini sejalan dengan penelitian Rahian dkk, dimana dari 276 pasien ditemukan pasien pada rentang 50.000-100.000 / 
$\mu$ sebanyak $67.4 \%$ dan pasien dengan trombosit dibawah $50.000 / \mu$ l sebanyak $32.6 \%$. Pada penelitian Danny dkk, dari 33 pasien anak dengan infeksi virus dengue terdapat pasien dengan trombosit dibawah $100.000 / \mu \mathrm{l}$ sebanyak $66.67 \% .{ }^{11-16}$ Hasil ini juga sejalan dengan penelitian Rosidah dkk, dari 30 pasien rerata jumlah trombosit pada pasien adalah $99.270 / \mu \mathrm{l}$. dengan standar deviasi 64.255/ $\mu .^{21}$ Kebocoran plasma sebagai salah satu manifestasi klinis infeksi virus dengue dapat menyebabkan bocornya trombosit dari kapiler darah sehingga menyebabkan penurunan kadar trombosit dalam darah. ${ }^{22}$

Hasil pemeriksaan hematokrit pada subyek penelitian didapatkan pasien dengan jumlah hematokrit dibawah $41 \%$ adalah yang terbanyak, diikuti pasien dengan rentang antara 41-46\%, kemudian pasien dengan jumlah lebih dari $46 \%$. Hasil ini serupa dengan penelitian yang dilakukan Rika dkk, dimana dari 67 pasien dengan DBD didapatkan pasien terbanyak dengan jumlah hematokrit dibawah $41 \%$ yaitu sebanyak $43.3 \%$ pasien, diikuti dengan pasien dengan rentang $41-45 \%$ yaitu sebanyak $41.8 \%$ pasien, serta pasien dengan hematokrit diatas $45 \%$ yaitu sebanyak $14.9 \%$ pasien. ${ }^{12}$ Hasil ini juga serupa dengan penelitian lain dari Raihan dkk, dan Danny dkk dimana pasien dengan hematokrit $<40 \%$ merupakan yang terbanyak dengan jumlah masing-masing $63 \%$ dan $45.7 \%$ pasien. ${ }^{11-16}$

Berdasarkan hasil pemeriksaan leukosit subyek penelitian didapatkan pasien dengan jumlah leukosit dibawah $5.000 / \mu \mathrm{l}$ adalah yang terbanyak, diikuti pasien dengan rentang leukosit 5.000-10.000 $/ \mu l$, dan kemudian pasien dengan jumlah diatas $10.000 / \mu 1$. Hasil ini cukup serupa dengan penelitian yang dilakukan Raihan dkk, dimana dari 276 pasien yang menjadi sampel, pasien dengan jumlah leukosit dibawah $5.000 / \mu$ l ditemukan sebanyak $76.8 \%$ sementara hanya ditemukan $23.2 \%$ pada pasien dengan leukosit diatas $5.000 / \mu \mathrm{l} .{ }^{11}$ Hasil juga serupa dengan penelitian Rosidah dkk, dimana dari 30 pasien yang menjadi sampel ditemukan rerata jumlah leukosit pasien adalah sebanyak $4.610 / \mu{ }^{21}$ Leukosit merupakan salah satu tanda yang sering digunakan untuk mengidentifikasi infeksi. Pada infeksi virus dengue manifestasi jumlah leukosit yang ditemukan pada pasien cenderung menurun. ${ }^{23}$

Berdasarkan hasil pemeriksaan temperatur aksila subyek penelitian, ditemukan pasien terbanyak datang dengan temperatur dibawah $37^{\circ} \mathrm{C}$, kemudian rentang temperatur $37-38^{\circ} \mathrm{C}$, diikuti pasien dengan temperatur diatas $38^{\circ} \mathrm{C}$. Hasil ini sedikit berbeda dengan penelitian yang dilakukan oleh Rika dkk, dimana dari 62 pasien sampel ditemukan $21 \%$ pasien dengan temperatur dibawah $38^{\circ} \mathrm{C}$, sementara pasien dengan temperatur diatas $38^{\circ} \mathrm{C}$ ada sebanyak $79 \%{ }^{12}$
Berdasarkan derajat infeksi dengue, pasien dengan derajat 1 ditemukan terbanyak, diikuti dengan derajat 3 , kemudian derajat 4 , terakhir derajat 2 memiliki jumlah paling sedikit. Hasil ini serupa dengan hasil penelitian Krisnanto dkk, dimana dari 852 pasien yang menjadi sampel, ditemukan pasien DBD derajat 1 sebanyak 51.4\%, pasien DBD derajat 2 sebanyak $35.7 \%$ dan pasien DBD derajat 3 dan 4 sebanyak $12.9 \% .{ }^{14}$ Hal ini juga serupa dengan penelitian dari Rosdiana dkk, di RSUD Abdul Wahab Sjahranie di Samarinda, dari 95 pasien yang menjadi sampel terdapat pasien DBD derajat 1 sebanyak 58.9\%, pasien derajat 2 sebanyak $27.4 \%$, pasien derajat 3 sebanyak $8.4 \%$ dan pasien derajat 4 sebanyak $5.3 \% .{ }^{24}$ Hasil ini juga serupa dengan penelitan dari Danny dkk, dimana dari 33 pasien yang menjadi sampel, pasien DBD derajat 1 dan 2 dominan dengan $69.7 \%$ dan $27.27 \%$ masing-masing. ${ }^{16}$

Jumlah pasien anak infeksi virus dengue, dari 54 pasien dengan infeksi derajat 1 didapatkan jumlah laki-laki sebanyak 20 pasien, dan jumlah perempuan sebanyak 34 pasien. Sementara dari 12 pasien dengan infeksi derajat 2 didapatkan 9 pasien lakilaki, dan 3 perempuan. Pada infeksi dengue derajat 3 , dari 16 pasien terdapat jumlah laki-laki sebanyak 10 pasien dan perempuan sebanyak 6 pasien. Pada infeksi dengue derajat 4, dari 14 pasien terdapat jumlah laki-laki sebanyak 5 pasien dan perempuan sebanyak 9 pasien. Hasil ini cukup serupa dengan penelitian oleh Rinang dkk, di RSUPN Ciptomangunkusumo dimana dari 12 pasien anak yang menjadi sampel didapatkan jumlah pasien dengan SSD atau infeksi derajat 3 dan 4 memiliki jumlah pasien laki-laki dan perempuan yang sama yaitu 3 orang. Sementara pasien dengan infeksi derajat 1 dan 2 didapatkan jumlah pasien lakilaki adalah 3 orang dan pasien perempuan adalah 4 orang. ${ }^{25}$

\section{SIMPULAN}

Pasien anak infeksi virus dengue yang dirawat di RSUP Sanglah ditemukan lebih banyak pasien perempuan, berusia 5-18 tahun, dan dengan status gizi normal. Dari segi gejala klinis penyakit pasien yang dominan datang ke poliklinik anak RSUP Sanglah memiliki tanda pendarahan dengan gejala terbanyak adalah tes torniquette positif, diikuti gejala klinis abdomen dengan gejala terbanyak adalah nausea, dan gejala klinis neurologis dengan gejala terbanyak adalah nyeri kepala. Pasien memiliki lama perawatan terbanyak selama 3-5 hari, dan hasil pemeriksaan temperatur aksial pada saat masuk rumah sakit terbanyak $<37^{\circ} \mathrm{C}$. Parameter laboratorium juga menunjukkan karakteristik yang khas pada pasien anak dengan infeksi virus dengue. 


\section{KONFLIK KEPENTINGAN}

Tidak terdapat konflik kepentingan dalam penulisan laporan penelitian ini.

\section{ETIKA PENELITIAN}

Penulis telah mendapatkan persetujuan etik dari Komisi Etik, Fakultas Kedokteran, Universitas Udayana, Bali sebelum penelitian berjalan.

\section{PENDANAAN}

Penulis bertangung jawab terhadap pendanaan penelitian secara mandiri.

\section{KONTRIBUSI PENULIS}

Seluruh penulis memiliki kontribusi yang sama dalam penulisan laporan penelitian ini baik dari tahap penyusunan kerangka konsep, pengambilan data, analisis data, hingga interpretasi data penelitian.

\section{DAFTAR PUSTAKA}

1. Bhatt S, Gething PW, Brady OJ, Messina JP, Farlow AW, Moyes CL, et al. The global distribution and burden of dengue. Nature. 2013;496(7446):504-507.

2. Stanaway JD, Shepard DS, Undurraga EA, Halasa YA, Coffeng LE, Brady OJ, et al. The global burden of dengue: an analysis from the Global Burden of Disease Study 2013. Lancet Infect Dis. 2016;16(6):712-723.

3. Guzman MG, Harris E. Dengue. Lancet. 2015; 385(9966):453-65.

4. Lam PK, Tam DT, Diet TV, Tam CT, Tien NT, Kieu NT, et al. Clinical characteristics of dengue shock syndrome in vietnamese children: A 10-year prospective study in a single hospital. Clin Infect Dis. 2013;57(11):1577-86.

5. Stahl HC, Butenschoen VM, Tran HT, Gozzer E, Skewes R, Mahendradhata $\mathrm{Y}$, et al. Cost of dengue outbreaks: literature review and country case studies. BMC Public Health. 2013;13:1048.

6. Karyanti MR, Hadinegoro SR. Perubahan Epidemiologi Demam Berdarah Dengue di Indonesia. Sari Pediatri. 2016;10(6) :424-32.

7. Maula AW, Fuad A, Utarini A. Ten-years trend of dengue research in Indonesia and South-east Asian countries: a bibliometric analysis. Glob Health Action. 2018;11(1):1504398.

8. Yoshikawa MJ, Kusriastuti R. Surge of dengue virus infection and chikungunya Fever in bali in 2010: the burden of mosquito-borne infectious diseases in a tourist destination. Trop Med Health. 2013;41(2):67-78.

9. Rajapakse S. Dengue shock. J Emerg Trauma Shock. 2011;4(1):120-127.
10. Suaya JA, Shepard DS, Beatty ME. Dengue: Burden of Disease and Costs of Illness. Special Programme for Research and Training in Tropical Diseases. 2006:35-49.

11. Raihan, Hadinegoro SRS, Timbelaka AR. Faktor Prognosis Terjadinya Syok pada Demam Berdarah Dengue. J Sari Pediatri. 2010;12(1):47-52.

12. Widyantari R. Perbedaan Gambaran Klinik Infeksi Dengue Pada Bayi Dan Anak Di Rsup Dokter Kariadi Semarang. Jurnal Kedokteran Diponegoro. 2012;1-39.

13. Indah J, Fadilah C. Status gizi berhubungan dengan derajat klinik infeksi Dengue Hemorrhagic Fever (DHF). NSJ. 2017;1(1) :2-10.

14. Krisnanto W, Juffrie M, Laksanawati IS, Mulatsih S. Pengaruh Transfusi Trombosit Terhadap Terjadinya Perdarahan Masif pada Demam Berdarah Dengue. J Sari Pediatri; 2011;12(6):404-8

15. Dominicus H, Rani C, Puspitasari D, Darmowandowo W, Basuki PS, Ismoedijanto. Profil Klinik Infeksi Virus Dengue pada Bayi di Surabaya. J Sari Pediatri. 2012;13(6):437-4.

16. Maharani DY, Apriliana E, Angraini DI. Hubungan Hasil Pemeriksaan Penunjang Terhadap Manifestasi Perdarahan Pasien Demam Berdarah Dengue Di SMF Anak RSUD Dr.A.Dadi Tjokrodipo Bandar Lampung. Majority. 2018;7(3):56-61

17. Zein DA, Hapsari D, Farhanah N. Gambaran karakteristik warning sign WHO 2009 pada penyakit Demam Berdarah Dengue (DBD) anak dan dewasa. Media Medika Muda. 2015;4(4):609-617.

18. Reni H, Lienggonegoro LA. Clinical and virological profile of Dengue cases: a study in Samarinda and Manado. Health Science Journal of Indonesia. 2018;9(2):76-81.

19. WHO. Handbook for Clinical Management of Dengue. Department of Control of Neglected Tropical Diseases. 2012:1-5

20. Sellahewa KH. Pathogenesis of Dengue Haemorrhagic Fever and Its Impact on Case Management. ISRN Infectious Diseases; 2013:1-6

21. Rosidah, Fauziah W. Hubungan Kadar Trombosit Dengan Leukosit pada Pasien DBD (Demam Berdarah Dengue) di Rumah Sakit Umum Haji Surabaya. J Sains. 2016;6(12):5-9.

22. Celia D. Dengue, Dengue Haemorrhagic Fever and Dengue Shock Syndrome in the Context of the Integrated Management of Childhood Illness. Department of Child and Adolescent Health and Development. 2005:2-11.

23. Potts JA, Rothman AL. Clinical and laboratory features that distinguish dengue from other febrile illnesses in endemic populations. Trop Med Int Health. 2008;13(11):1328-40.

24. Rosdiana, Tjeng WS, Sudarso S. Hubungan antara Hasil Pemeriksaan Leukosit, Trombosit dan Hematokrit dengan Derajat Klinik DBD pada Pasien Anak Di RSUD Abdul Wahab Sjahranie Samarinda. J Sari Pediatri. 2017;19(1):41-45

25. Rinang M, Rezeki S, Hadinegoro S. Profil Klinis, Laboratorium, dan Serologi Infeksi Virus Dengue pada Bayi. J Sari Pediatri; 2015;16(6):441-6.

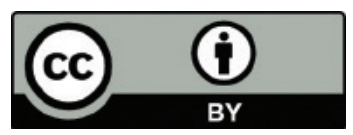

This work is licensed under a Creative Commons Attribution 